\title{
Effects of intravenously administered indocyanine green on near-infrared cerebral oximetry and pulse oximetry readings
}

\author{
Ho Young Baek, Hyun-jung Lee, Joung Min Kim, Soo-young Cho, \\ Seongtae Jeong, and Kyung Yeon Yoo \\ Department of Anesthesiology and Pain Medicine, Chonnam National University Hospital, Gwangju, Korea
}

\begin{abstract}
Background: Intravenously administered indocyanine green (ICG) may cause misreadings of cerebral oximetry and pulse oximetry in patients undergoing carotid endarterectomy under general anesthesia. The present study determined the effects of two different doses (12.5 mg vs. $25 \mathrm{mg}$ ) of ICG on regional cerebral tissue oxygen saturation $\left(\mathrm{SctO}_{2}\right)$ and percutaneous peripheral oxygen saturation $\left(\mathrm{SpO}_{2}\right)$.

Methods: Twenty-six patients receiving ICG for videoangiography were divided into two groups according to the dosage (12.5 mg and $25 \mathrm{mg}, \mathrm{n}=13$ in each group). Heart rate, arterial blood pressure, $\mathrm{SctO}_{2}$, and $\mathrm{SpO}_{2}$ were measured before and after an intravenous bolus administration of ICG.

Results: Following the dye administration, no changes in heart rate or arterial blood pressure were noted in either group. $\mathrm{SctO}_{2}$ was increased in both groups; however, the magnitude of the increase was greater $(21.6 \pm 5.8 \%$ vs. $12.6 \pm 4.1 \%$, $\mathrm{P}<0.0001)$ and more prolonged $(28.4 \pm 9.6 \mathrm{~min}$ vs. $13.8 \pm 5.2 \mathrm{~min}, \mathrm{P}<0.0001)$ in the $25 \mathrm{mg}$ group than in the $12.5 \mathrm{mg}$ group. In contrast, $\mathrm{SpO}_{2}$ was decreased in both groups; the magnitude of the decrease was greater in the $25 \mathrm{mg}$ group than in the $12.5 \mathrm{mg}$ group $(4.0 \pm 0.8 \%$ vs. $1.6 \pm 1.0 \%, \mathrm{P}<0.0001)$. There were no differences in the time to reach the peak $\mathrm{SctO}_{2}$ or to reach the nadir $\mathrm{SpO}_{2}$ between the two groups.

Conclusions: In patients given ICG for videoangiography, a $25 \mathrm{mg}$ bolus results in a greater and more prolonged increase in $\mathrm{SctO}_{2}$ and a greater reduction in $\mathrm{SpO}_{2}$ than a $12.5 \mathrm{mg}$ bolus, with no differences in the time to reach the peak $\mathrm{SctO}_{2}$ or to reach the nadir $\mathrm{SpO}_{2}$.
\end{abstract}

Key Words: Cerebral oximetry, Cerebral oxygenation, Indocyanine green, Near-infrared spectroscopy, Pulse oximetry.

Corresponding author: Kyung Yeon Yoo, M.D., Ph.D.

Department of Anesthesiology and Pain Medicine, Chonnam

National University Hospital, 42, Jebong-ro, Dong-gu, Gwangju 501-

190, Korea

Tel: 82-62-220-6893, Fax: 82-62-232-6294

E-mail: kyyoo@jnu.ac.kr

Received: August 26, 2014.

Revised: 1st, September 19, 2014; 2nd, September 22, 2014.

Accepted: September 23, 2014.

Korean J Anesthesiol 2015 April 68(2): 122-127

http://dx.doi.org/10.4097/kjae.2015.68.2.122

\section{Introduction}

It is well established that intravenously administered vital dyes having absorption spectra used by optical-technologybased monitors interfere with oximetry readings. They may then result in misreadings of percutaneous oxygen saturation $\left(\mathrm{SpO}_{2}\right)$ measured via pulse oximetry, although it is transient $[1,2]$.

Cerebral near-infrared spectroscopy (NIRS), which provides real-time information on the balance between cerebral oxygen supply and demand, also uses infrared light to estimate regional

(c) This is an open-access article distributed under the terms of the Creative Commons Attribution Non-Commercial License (http://creativecommons.org/ licenses/by-nc/3.0/), which permits unrestricted non-commercial use, distribution, and reproduction in any medium, provided the original work is properly cited. 
cerebral tissue oxygen saturation $\left(\mathrm{SctO}_{2}\right)[3,4]$. It is now being increasingly used to guide intraoperative optimization of cerebral oxygenation in patients undergoing procedures associated with a high risk of adverse neurologic outcomes [5]. However, among others, methylene blue [6] and indigo carmine [7] may interfere with NIRS-based cerebral oximetry readings.

Indocyanine green (ICG) is a strong near-infrared absorber having preferable fluorescent characteristics. It has been used to visualize the blood stream during neurosurgery [8], being particularly useful for observing the patency of extracranialintracranial bypass [9], for complete aneurysm clipping [10], or for the intraoperative evaluation of carotid endarterectomy (CEA) [11]. Many new intraoperative applications of ICG and ICG angiography are emerging $[12,13]$.

We have recently documented a constant and immediate increase in $\mathrm{SctO}_{2}$ readings with the INVOS ${ }^{\circledR}$ device in patients undergoing neurosurgery during which an IV bolus of $12.5 \mathrm{mg}$ ICG (approximately $0.25 \mathrm{mg} / \mathrm{kg}$ ) was administered for videoangiography [14]. However, two dosages of ICG (12.5 mg or $25 \mathrm{mg}$ ) are frequently used in clinical practice, while its recommended dose for standard diagnostic procedures ranges between 0.1 and $0.5 \mathrm{mg} / \mathrm{kg}$ with a maximum daily dose of $5 \mathrm{mg} / \mathrm{kg}$ [10]. The magnitude and the duration of $\mathrm{SctO}_{2}$ misreading may vary as a function of different doses of ICG. The current study aimed to determine the oximetry readings $\left(\mathrm{SctO}_{2}\right.$ and $\left.\mathrm{SpO}_{2}\right)$ using two different doses (12.5 mg vs. $25 \mathrm{mg}$ ) of ICG during CEA under general anesthesia. Cerebral oximetry and near-infraredICG videoangiography have been used simultaneously for many years in patients undergoing neurovascular surgeries on a routine basis in our hospital.

\section{Materials and Methods}

After receiving the University Hospital Ethics Committee approval, written informed consent was obtained from all of the patients. Twenty-six patients of American Society of Anesthesiologists (ASA) physical status I-III scheduled for CEA under general anesthesia with tracheal intubation were assigned to either the $12.5 \mathrm{mg}$ group or the $25 \mathrm{mg}$ group, based on a computer-generated randomization list. Exclusion criteria included liver or renal insufficiency, known iodine or ICG hypersensitivity, and ASA physical status IV or V.

Patients were premedicated with midazolam $0.1 \mathrm{mg} / \mathrm{kg}$ orally $60 \mathrm{~min}$ before being transported to the operating room. Upon arrival in the operating room, standard monitoring including electrocardiography, noninvasive measurement of systemic blood pressure, pulse oximetry, capnography, and bispectral index monitoring $\left(\mathrm{BIS}^{\circledR}\right.$ system; Aspect Medical Systems, Newton, MA, USA) was applied throughout the procedure. A 20-gauge radial arterial catheter was placed in either wrist of each sub- ject under local anesthesia with $1 \%$ lidocaine to monitor blood pressure and to take blood samples if necessary. Pulse oximetry finger probe (Ohmeda Biox 3700, Ohmeda, Louisville, CO, USA) was placed on the index finger of the hand. Two adhesive cerebral oximeter probes were applied to the forehead before induction of anesthesia to continuously measure $\mathrm{SctO}_{2}$ using the INVOS $^{\circledR} 5100 \mathrm{~B}$ cerebral oximeter (INVOS ${ }^{\circledR}$, Somanetics; Troy, $\mathrm{MI}, \mathrm{USA})$. $\mathrm{SctO}_{2}$ values contralateral to the side of surgery were used to determine cerebral oxygenation.

After preoxygenation, anesthesia was induced with IV propofol (1 to $2 \mathrm{mg} / \mathrm{kg}$ ) and remifentanil $(1 \mu \mathrm{g} / \mathrm{kg})$, and maintained with sevoflurane (1.5 to $2.0 \%$ ) and remifentanil (0.03 to $0.12 \mu \mathrm{g} /$ $\mathrm{kg} / \mathrm{min}$ ). Rocuronium was used for initiation and maintenance of muscle relaxation. Patients were mechanically ventilated after tracheal intubation with an oxygen/air mixture at 0.5 fraction of inspired oxygen to maintain the end-tidal carbon dioxide tension between 35 and $40 \mathrm{mmHg}$ throughout the surgery.

During the surgery, near-infrared-ICG videoangiographic recording was performed before and/or after the excision of the plaque and closure of the ICA. Upon the surgeon's request, patients were given ICG (Indocyanine green ${ }^{\circledR}$, Dongin-Dang Pharmaceuticals, Seoul, Korea) intravenously by the anesthesiologist as a bolus of $12.5 \mathrm{mg}$ (approximately $0.25 \mathrm{mg} / \mathrm{kg}$ dose) or $25 \mathrm{mg}$ (approximately $0.5 \mathrm{mg} / \mathrm{kg}$ dose, $25 \mathrm{mg}$ dose dissolved in $10 \mathrm{ml}$ of $0.9 \% \mathrm{NaCl}$ ) to visualize the blood flow within the internal carotid artery.

Heart rate, arterial blood pressure, $\mathrm{SctO}_{2}$, and $\mathrm{SpO}_{2}$ were recorded by an independent investigator immediately before anesthetic induction and just before administration of ICG (baseline), and every min thereafter until the recovery of baseline $\mathrm{SctO}_{2}$ value. The time from dye injection to the maximum changes (peak or nadir) and to the recovery of baseline values (duration) of $\mathrm{SctO}_{2}$ and $\mathrm{SpO}_{2}$, the highest readings of $\mathrm{SctO}_{2}$ (peak) or the lowest readings of $\mathrm{SpO}_{2}$ (nadir), and the magnitude of their maximum changes after ICG injection were also recorded.

\section{Statistical analysis}

The sample size calculation was based on the primary endpoint of $\mathrm{SctO}_{2}$ value after ICG injection. A power analysis suggested that a sample size of 10 patients in each group should be adequate to detect an absolute $5 \%$ difference in the highest $\mathrm{SctO}_{2}$ value with a two-sided significance level (alpha) of 0.05 and a power of 0.8 . Data are expressed as mean $\pm \mathrm{SD}$ (range). Both between and within group comparisons of $\mathrm{SctO}_{2}, \mathrm{SpO}_{2}$, and hemodynamic data were analyzed using two-way repeated measures analysis of variance followed by Scheffé post hoc test as required. Normal distribution was determined using the KolmogorovSmirnov test. Categorical data were analyzed using the Fisher's exact test. Other data were compared between the groups us- 
ing a paired Student's t-test. All analyses were performed using StatView software version 4.0 (Abacus Concepts, Berkeley, CA, USA). A P value $<0.05$ was considered statistically significant.

\section{Results}

Consecutive ICG videoangiographic examinations were performed in 26 patients; 21 before and the remaining 5 after arteriotomy. The patient characteristics including the baseline $\mathrm{SctO}_{2}$ and $\mathrm{SpO}_{2}$ were comparable between the two groups (Table 1).

Table 1. Demographic and Intraoperative Variables

\begin{tabular}{|c|c|c|c|}
\hline Variables & $\begin{array}{c}12.5 \text { mg Group } \\
(n=13)\end{array}$ & $\begin{array}{c}25 \text { mg Group } \\
(\mathrm{n}=13)\end{array}$ & $P$ value \\
\hline Male/Female & $9 / 4$ & $10 / 3$ & 0.658 \\
\hline Age (yr) & $67.1(56-77)$ & $68.1(58-78)$ & 0.750 \\
\hline Weight (kg) & $62.3 \pm 11.5$ & $64.9 \pm 9.0$ & 0.525 \\
\hline Hemoglobin (g/dl) & $13.3 \pm 1.0$ & $12.4 \pm 2.3$ & 0.189 \\
\hline \multicolumn{4}{|l|}{ Underlying diseases } \\
\hline Hypertension & 7 & 8 & 0.691 \\
\hline Diabetes & 2 & 6 & 0.089 \\
\hline MAP before ICG (mmHg) & $74.7 \pm 8.7$ & $69.8 \pm 7.7$ & 0.139 \\
\hline HR before ICG (beats/min) & $64.6 \pm 14.4$ & $74.5 \pm 12.4$ & 0.074 \\
\hline $\mathrm{SctO}_{2}$ before ICG $(\%)$ & $62.0 \pm 4.2$ & $60.5 \pm 6.4$ & 0.473 \\
\hline $\mathrm{SpO}_{2}$ before ICG (\%) & $98.7 \pm 1.6$ & $98.2 \pm 1.3$ & 0.334 \\
\hline
\end{tabular}

Data are expressed as mean (range), mean \pm SD or numbers. ACEI angiotensin converting enzyme inhibitor, Ag II a: angiotensin II antagonist, MAP: mean arterial pressure, $\mathrm{HR}$ : heart rate, $\mathrm{SctO}_{2}$ : regional cerebral tissue oxygen saturation, $\mathrm{SpO}_{2}$ : percutaneous peripheral oxygen saturation.

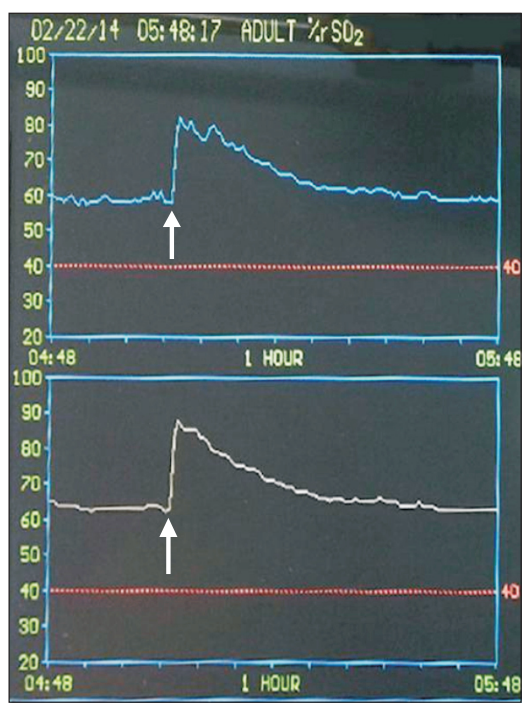

Fig. 1. A rapid but transient increase in near-infrared cerebral oximetry reading (upper, left; lower, right) after intravenous indocyanine green injection as a bolus ( $25 \mathrm{mg}$, administered at the point indicated by the arrow).
No changes in heart rate or arterial blood pressure were noted following the dye administration in either group.

Fig. 1 illustrates the typical changes in $\mathrm{SctO}_{2}$ after a $25 \mathrm{mg}$ bolus injection of ICG in a patient by replicating the INVOS monitor display. Following the administration, $\mathrm{SctO}_{2}$ was significantly increased in both groups; however, the magnitude of the increase of was greater $(21.6 \pm 5.8 \%$ vs. $12.6 \pm 4.1 \%, \mathrm{P}<0.0001)$ and more prolonged $(28.4 \pm 9.6 \mathrm{~min}$ vs. $13.8 \pm 5.2 \mathrm{~min}, \mathrm{P}<$ 0.0001 ) in the $25 \mathrm{mg}$ group than in the $12.5 \mathrm{mg}$ group (Fig. 2). No differences were noted between the two groups in the time to reach the greatest changes in $\mathrm{SctO}_{2}(43.0 \pm 10.9 \mathrm{~s}$ vs. $50.0 \pm$ $30.0 \mathrm{~s}, \mathrm{P}=0.437)$. Also, there were no significant differences in the degree of maximum increases in $\mathrm{SctO}_{2}$ between the nonoperative and operative sides in either the $12.5 \mathrm{mg}$ group $(12.6 \pm$ $4.1 \%$ vs. $12.7 \pm 3.4 \%, \mathrm{P}=0.910)$ or the $25 \mathrm{mg}$ group $(21.6 \pm 5.8 \%$

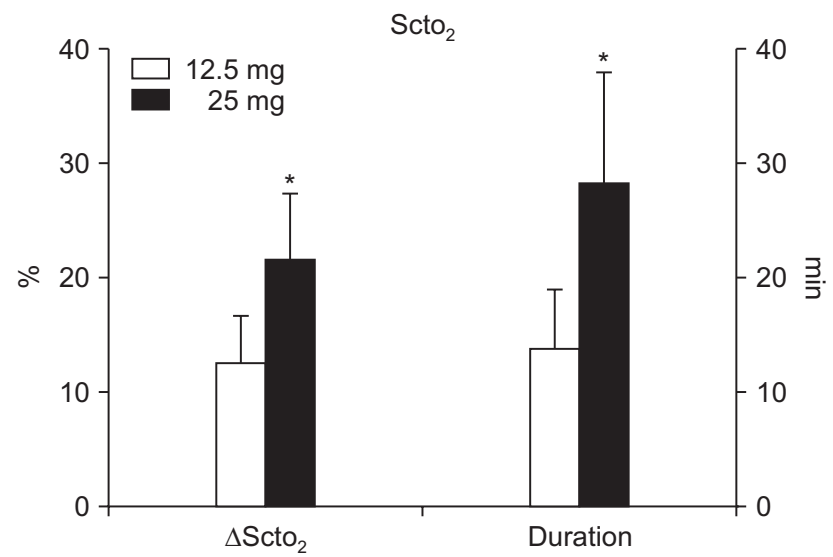

Fig. 2. The magnitude $\left(\Delta \mathrm{SctO}_{2}\right)$ and duration of the increase in regional cerebral oxygen saturation $\left(\mathrm{SctO}_{2}\right)$ via cerebral oximetry after intravenous indocyanine green injection as a bolus (12.5 mg or $25 \mathrm{mg}$ ). Data shown are expressed as mean $\pm \mathrm{SD}$. $* \mathrm{P}<0.05$ vs. $12.5 \mathrm{mg}$.

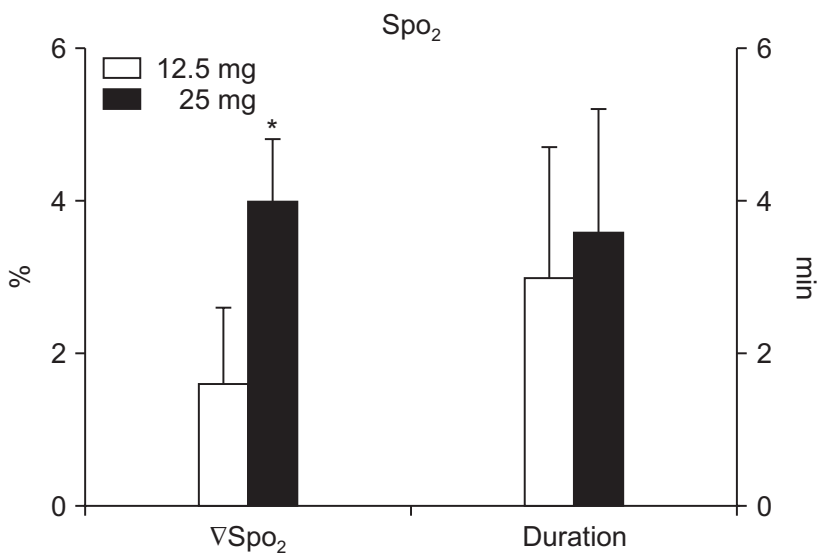

Fig. 3. The magnitude $\left(\nabla \mathrm{SpO}_{2}\right)$ and duration of the decrease in percutaneous peripheral oxygen saturation $\left(\mathrm{SpO}_{2}\right)$ via pulse oximetry after intravenous indocyanine green injection as a bolus (12.5 mg or $25 \mathrm{mg}$ ). Data shown are expressed as mean $\pm \mathrm{SD} .{ }^{*} \mathrm{P}<0.05$ vs. $12.5 \mathrm{mg}$. 
vs. $19.7 \pm 3.6 \%, \mathrm{P}=0.054)$.

In contrast, $\mathrm{SpO}_{2}$ was significantly decreased in both groups $(\mathrm{P}<0.005)$; the magnitude of the decrease was greater in the 25 mg group than in the $12.5 \mathrm{mg}$ group $(4.0 \pm 0.8 \%$ vs. $1.6 \pm 1.0 \%$, $\mathrm{P}<0.0001)$. There were no differences between the two groups in the time to reach the nadir $\mathrm{SpO}_{2}(47.5 .0 \pm 20.0 \mathrm{~s}$ vs. $57.5 \pm$ $37.4 \mathrm{~s}, \mathrm{P}=0.404$ ) (Fig. 3) and the time to recover to the baseline $\mathrm{SctO}_{2}(3.6 \pm 1.6 \mathrm{~min}$ vs. $3.0 \pm 1.7 \mathrm{~min}, \mathrm{P}=0.374)$.

An immediate increase in $\mathrm{SctO}_{2}$ was observed in all of the patients, whereas a decrease in $\mathrm{SpO}_{2}$ was observed in all but one patient (96.2\%). Overall, the highest $\mathrm{SctO}_{2}$ values were 86 and $95 \%$ and the lowest $\mathrm{SpO}_{2}$ values were 94 and $92 \%$ in the 12.5 and $25 \mathrm{mg}$ groups, respectively.

\section{Discussion}

Our study demonstrated that, when given as a single IV bolus using the INVOS cerebral oximeter, the higher dose (25 mg) of ICG led to greater and more prolonged increases in $\mathrm{SctO}_{2}$ with a greater reduction in $\mathrm{SpO}_{2}$, reaching the peak or the nadir within a minute (approximately one or two circulation times). These results are contradictory to those previously obtained with methylene blue [6] or indigo carmine [7], where $\mathrm{SctO}_{2}$ was significantly decreased. Collectively, interference with the $\mathrm{SctO}_{2}$ measurement (i.e., the magnitude, duration, and direction of the changes) by the vital dyes may vary according to the dosage as well as the type of the dye.

The INVOS cerebral oximeter uses two near-infrared wavelengths (730 and $805 \mathrm{~nm}$ ) and measures the spectral absorbance of an admixture of arterial, capillary, and venous blood (hemoglobin or cytochrome aa3) in the brain [15]. Regional oxygen saturation is calculated as the ratio of oxyhemoglobin to total hemoglobin determined by the differential light absorption with subsequent computer suppression of the input from superficial tissues [3]. Any substance that absorbs infrared light of the same wavelength produced by the light emitting diodes may affect the absorption of light as it traverses the blood and tissues.

ICG has a dose- and time-dependent effect on plasma light absorbance (range 700-850 nm) with a spectral absorption peak at $805 \mathrm{~nm}$ and an emission peak around $835 \mathrm{~nm}$, which is within the NIR window [16], whereas indigo carmine has an absorption peak at $620 \mathrm{~nm}$ with a dramatic decline around $700 \mathrm{~nm}$ [1]. Deoxyhemoglobin absorbs more infrared light at $730 \mathrm{~nm}$, with the isobestic point for deoxyhemoglobin/oxyhemoglobin (wavelength at which oxy- and deoxyhemoglobin species have the same molar absorptivity) at $810 \mathrm{~nm}$. Taken together, ICG would reduce the ratio of infrared light absorption at $730 \mathrm{~nm} / 805 \mathrm{~nm}$ with a resultant increase in $\mathrm{SctO}_{2}$, while indigo carmine would increase the ratio with resultant dampening of $\mathrm{SctO}_{2}$.

Fluorescent lights have been shown to interfere with pulse oximetry readings [17]. ICG becomes strongly NIR-fluorescent after IV administration, with an absorption and an emission peak within the range of wavelengths used by the INVOS device [16]. In this context, one may ascribe the enhanced $\mathrm{SctO}_{2}$ readings to a strong fluorescence signal emitted by ICG. This is, however, unlikely because the emission detected by the INVOS device would be a reduction in oxy-hemoglobin and $\mathrm{SctO}_{2}$.

ICG increased $\mathrm{SctO}_{2}$, whose peak was shown within one minute after the administration in the present study; while indigo carmine caused a nadir in $7 \mathrm{~min}(5-9 \mathrm{~min})$ in a previous study [7]. The peak effects may be related to the highest concentration of the drug within the blood compartment in the brain tissue, since neither indigo carmine nor ICG normally penetrates the blood-brain barrier. Both dyes reach their peak concentrations in the brain within a minute when administered intravenously or intraarterially $[18,19]$. The discrepancy in the time to reach the peak $\mathrm{SctO}_{2}$ between the two dyes cannot be readily explained. ICG may increase $\mathrm{SctO}_{2}$ very rapidly (within one minute), since the wavelength of light (i.e., $805 \mathrm{~nm}$ ) emitted by the INVOS System is very close to the absorption peak of ICG with a resultant extremely high absorbance.

Cerebral oximetry, in contrast to $\mathrm{SpO}_{2}$ monitoring based on transmission oximetry, uses reflectance oximetry to measure the oxygen saturation of the tissues underneath the sensor. The light passes not only through parts of the frontal brain, but also through the overlying skull and scalp, and the oximetry signal may thus be contaminated by extracranial blood sources [20]. One may argue if cross clamping of the carotid artery during the surgery may redistribute the blood flow between extracranial and intracranial tissues and thereby increases the extracranial blood volume where hemoglobin oxygen saturation would be higher compared to that in the intracranial blood, $\mathrm{SctO}_{2}$ would be increased. However, in the present study, the changes in contralateral and ipsilateral $\mathrm{SctO}_{2}$ values after ICG did not differ in either group. Moreover, videoangiography was not performed during the carotid artery occlusion, but it was performed before the occlusion and/or following the reperfusion. It is unlikely that the redistribution of blood flow contributed to the elevated $\mathrm{SctO}_{2}$ reading.

ICG-induced increase in $\mathrm{SctO}_{2}$ was dose-dependent by the $12.6-21.6 \%$ absolute changes (20-36\% relative changes), which lasted for up to 28 minutes with the higher dose. The relative increase in $\mathrm{SctO}_{2}>20 \%$ after carotid declamping has been associated with the onset of cerebral hyperperfusion syndrome in patients undergoing CEA under general anesthesia [21], whereas the relative decrease in $\mathrm{SctO}_{2}>20 \%$ after carotid crossclamping has been associated with cerebral ischemia [22]. As such, the elevation of $\mathrm{SctO}_{2}$ readings temporarily induced by ICG may obscure the interpretation of $\mathrm{SctO}_{2}$ changes during the surgery, preventing the use of proper therapeutic interventions 
(e.g., shunt placement or other pharmacological or physiological intervention) to correct the changes in $\mathrm{SctO}_{2}$ and to improve postoperative outcomes. Moreover, administration of the dye is usually repeated in every patient because angiography is performed twice, i.e., before and after arteriotomy, in CEA procedures.

In the present study, the change in $\mathrm{SctO}_{2}$ lasted longer than that in $\mathrm{SpO}_{2}$. The pulse oximeter measures hemoglobin saturation in the arterial bed using two wavelengths of light (660 and $925 \mathrm{~nm}$ ), while ICG has an absorption peak at $805 \mathrm{~nm}$. The INVOS device measures regional cerebral tissue oxygen saturation (i.e., venous, capillary, and arterial blood) using two nearinfrared wavelengths (730 and $805 \mathrm{~nm}$ ). Differences in blood beds evaluated by the monitors, and the employed wavelengths and the analysis methods of the two devices (i.e., pulse oximeter and cerebral oximeter) may, at least in part, account for the differences in their interaction with ICG. Consequently, cere- bral oxygenation monitoring using NIRS is more sensitive to changes in ICG than pulse oximetry. A dampened $\mathrm{SctO}_{2}$ reading persisted for 20-40 min with indigo carmine in a previous study [5], while an elevated $\mathrm{SctO}_{2}$ reading was maintained for $13.8 \pm$ $5.2 \mathrm{~min}$ with ICG $12.5 \mathrm{mg}$ and $28.4 \pm 9.6 \mathrm{~min}$ with ICG $25 \mathrm{mg}$ in the present study. We speculate that the effects of the two dyes on $\mathrm{SctO}_{2}$ persist until the dyes are completely cleared up from the circulation (i.e., 5 to 6 half-lives) because of their higher sensitivity.

In conclusion, in patients undergoing CEA under general anesthesia, an IV bolus of $25 \mathrm{mg}$ ICG for videoangiography resulted in a greater and more prolonged increase (for up to 28 min with a higher dose) in $\mathrm{SctO}_{2}$ and a greater decrease in $\mathrm{SpO}_{2}$ than an IV bolus of $12.5 \mathrm{mg}$ ICG, with no differences in the time to reach the peak $\mathrm{SctO}_{2}$ or the nadir $\mathrm{SpO}_{2}$. Anesthesiologists should be alert when cerebral oximetry and IV-administered ICG are being used simultaneously.

\section{References}

1. Scheller MS, Unger RJ, Kelner MJ. Effects of intravenously administered dyes on pulse oximetry readings. Anesthesiology 1986; 65: 550-2.

2. Sidi A, Paulus DA, Rush W, Gravenstein N, Davis RF. Methylene blue and indocyanine green artifactually lower pulse oximetry readings of oxygen saturation. Studies in dogs. J Clin Monit 1987; 3: 249-56.

3. Murkin JM, Arango M. Near-infrared spectroscopy as an index of brain and tissue oxygenation. Br J Anaesth 2009; 103 Suppl 1: i3-13.

4. Yoshitani K, Kawaguchi M, Tatsumi K, Kitaguchi K, Furuya H. A comparison of the INVOS 4100 and the NIRO 300 near infrared spectrophotometers. Anesth Analg 2002; 94: 586-90.

5. Ghosh A, Elwell C, Smith M. Review article: cerebral near-infrared spectroscopy in adults: a work in progress. Anesth Analg 2012; 115: 1373-83.

6. Mittnacht AJ, Fischer GW, Reich DL. Methylene blue administration is associated with decreased cerebral oximetry values. Anesth Analg 2007; 105: 549-50.

7. McDonagh DL, McDaniel MR, Monk TG. The effect of intravenous indigo carmine on near-infrared cerebral oximetry. Anesth Analg 2007; 105: 704-6.

8. Giraudeau C, Moussaron A, Stallivieri A, Mordon S, Frochot C. Indocyanine Green: Photosensitizer or Chromophore? Still a Debate. Curr Med Chem 2013 [Epub ahead of print].

9. Woitzik J, Horn P, Vajkoczy P, Schmiedek P. Intraoperative control of extracranial-intracranial bypass patency by near-infrared indocyanine green videoangiography. J Neurosurg 2005; 102: 692-8.

10. Raabe A, Nakaji P, Beck J, Kim LJ, Hsu FP, Kamerman JD, et al. Prospective evaluation of surgical microscope-integrated intraoperative near-infrared indocyanine green videoangiography during aneurysm surgery. J Neurosurg 2005; 103: 982-9.

11. Haga S, Nagata S, Uka A, Akagi Y, Hamada Y, Shono T. Near-infrared indocyanine green videoangiography for assessment of carotid endarterectomy. Acta Neurochir (Wien) 2011; 153: 1641-4.

12. Kokudo N, Ishizawa T. Clinical application of fluorescence imaging of liver cancer using indocyanine green. Liver Cancer 2012; 1: 15-21.

13. Alander JT, Kaartinen I, Laakso A, Pätilä T, Spillmann T, Tuchin VV, et al. A review of indocyanine green fluorescent imaging in surgery. Int J Biomed Imaging 2012; 2012: 940585.

14. Yoo KY, Baek HY, Jeong S, Hallacoglu B, Lee J. Intravenously administered indocyanine green may cause falsely high near-infrared cerebral oximetry readings. J Neurosurg Anesthesiol 2015; 27: 57-60.

15. Watzman HM, Kurth CD, Montenegro LM, Rome J, Steven JM, Nicolson SC. Arterial and venous contributions to near-infrared cerebral oximetry. Anesthesiology 2000; 93: 947-53.

16. Shimizu S, Kamiike W, Hatanaka N, Yoshida Y, Tagawa K, Miyata M, et al. New method for measuring ICG Rmax with a clearance meter. World J Surg 1995; 19: 113-8.

17. Amar D, Neidzwski J, Wald A, Finck AD. Fluorescent light interferes with pulse oximetry. J Clin Monit 1989; 5: 135-6.

18. Reif R, Wang M, Joshi S, A'Amar O, Bigio IJ. Optical method for real-time monitoring of drug concentrations facilitates the development of novel methods for drug delivery to brain tissue. J Biomed Opt 2007; 12: 034036. 
19. Gora F, Shinde S, Elwell CE, Goldstone JC, Cope M, Delpy DT, et al. Noninvasive measurement of cerebral blood flow in adults using nearinfrared spectroscopy and indocyanine green: a pilot study. J Neurosurg Anesthesiol 2002; 14: 218-22.

20. Davie SN, Grocott HP. Impact of extracranial contamination on regional cerebral oxygen saturation: a comparison of three cerebral oximetry technologies. Anesthesiology 2012; 116: 834-40.

21. Pennekamp CW, Immink RV, den Ruijter HM, Kappelle LJ, Bots ML, Buhre WF, et al. Near-infrared spectroscopy to indicate selective shunt use during carotid endarterectomy. Eur J Vasc Endovasc Surg 2013; 46: 397-403.

22. Pennekamp CW, Immink RV, den Ruijter HM, Kappelle LJ, Ferrier CM, Bots ML, et al. Near-infrared spectroscopy can predict the onset of cerebral hyperperfusion syndrome after carotid endarterectomy. Cerebrovasc Dis 2012; 34: 314-21. 